\title{
Correspondence
}

\section{Postgraduate training in psychiatry}

Sir: As a former trainee in psychiatry in The Netherlands I would like to make the following comments on the article by Hall \& Robertson (Psychiatric Bulletion, August 1996, 20, 482-484). After receiving the Certificate of Completion of Specialist Training (CCST) child psychiatrists spend a further year in their speciality for which they recetve an additional certificate, provided they have spent a 12 month period of training in child psychiatry during their rotation. Otherwise they need an additional two years in child psychiatry to obtain this certificate (Centraal College, 1994).

Hall \& Robertson report that trainees in psychiatry are shielded from an excessive clinical work-load. This is mainly true for trainees in University Hospitals. However, of the 20 psychiatric hospitals in The Netherlands which have training approval only eight are University Hospitals. This means that the majority of trainees do not enjoy this privilege and, in fact, they often have a clinical work-load twice the size of their academic counterparts.

It is true that the MRCPsych is being recognised as a postgraduate qualification in The Netherlands. However, this does not mean that a person having acquired this qualification is automatically eligible for a CCST and specialist status in The Netherlands. It requires the member to work for a period of time (on average a year) under the supervision of a Head of Department (or teaching director) after which the Head of Department can recommend specialist eligibility to the Central College of Medical Specialists (Centraal College, 1982).

Furthermore, in 1991 there were three members of the College working in The Netherlands (Royal College of Psychiatrists, 1991), while there are currently 12 members doing so (personal communication, Registration Officer, Royal College of Psychiatrists). So, although there is the theoretical possibility of "progressing to consultant in the fast lane", the reality is that the total number of Dutch trainees obtaining the MRCPsych remains negligible.

CENTRAAL COLLEG (1982) Inschrijving in specialistenregister van in het buitenland opgeleide medische spectalisten. Medisch Contact, 30, 151-153.

- (1994) Opleidingseisen psychiatrie. Medisch Contact, 8. 269-279.

Royal College of PSYchIATRISTS (1991) Membership List. Dorchester: Dorset Press.

WALTER P. BOUMAN, Department of Health Care of the Elderly, University Hospital Queen's Medical Centre, Nottingham NG7 $2 U \mathrm{H}$
Sir: There has been recent correspondence in your Journal about the effects of the Calman changes on psychiatric training (Caldicott, $1996 a$ ) and in particular the compatibility of our training with that in other EU countries. I have concerns that the way Calman has been implemented in psychiatry will disadvantage the future recruitment of doctors into psychiatry and have almost no effect on standardising our training with the rest of Europe.

It is said that "Psychiatric training in Britain and Ireland will take six to seven years" (Caldicott, $1996 b)$. This is not the case. In order to sit the Part II of the MRCPsych examination one must have completed three years of training and must sit it while in a training job, therefore having done at least 312 years before they will be ready to apply for a specialist registrar job. I would wholeheartedly support the views of Cervilla \& Warner (1996) that to obtain accreditation in only one of the four psychiatric specialities (which are unrecognised in either the EU or Commonwealth countries) would be seen as a disadvantageous career move. Hence a majority of trainees are likely to spend four years at the senior registrar grade.

British training at $7 \frac{1}{2}$ years (minimum) compares with a Portuguese, Greek or Belgian training of 4 years (in Belgium with no formal examination). Any British medical graduate who wished to pursue a career in psychiatry would be well advised to undertake their training in one of these European countries and return fully accredited for Consultant work.

CALDICOTT, F. (1996a) Certificate of Completion of Specialist Training (CCST): implications for higher training in psychiatry. Psychiatric Bulletin, 20, 372-337.

- (1996b) Training in psychiatry in Europe. Advances in Psychlatric Treatment, 2, 141-142.

Cervilua, J. J. \& WARNER, J. P. (1996) Certificate of Completion of Specialist Training (CCST): implications for higher training in psychiatry. Psychiatric Bulletin, 20 372.

JOHN SANDFORD, Stoke Park Hospital, Bristol BS16 1QU

\section{Fellowships of Royal Colleges}

Sir: In the September issue of the Bulletin, Dr Moliver questions the role of Fellowships in Royal Colleges and suggests that they could be abolished (Psychiatric Bulletin, 20, 565). An alternative approach is to develop Fellowship as a high 